URSZULA NOWICKA

Uniwersytet Kardynała Stefana Wyszyńskiego w Warszawie

\title{
WZAJEMNE POWIĄZANIA KPK I KKKW NA PLASZCZYŹNIE ICH AUTONOMICZNEGO FUNKCJONOWANIA
}

Treść: Wstęp. - 1. Zasada współistnienia, ale nie podporządkowania KPK i KKKW. - 2. Zasada nisi, relationes cum Ecclesia latina quod attinet, aliud expresse statuitur. - 3. Kościół sui iuris a Ecclesia latina w normach KKKW. - 4. Komplementarność praktyczna KKKW i KPK jako jednego systemu prawnego. - Zakończenie.

Nie ma watpliwości, że promulgacja Kodeksu Kanonów Kościołów Wschodnich (KKKW), której dokonał Jan Paweł II w siedem lat po ukazaniu się Kodeksu prawa kanonicznego (KPK), była dla prawa kanonicznego wydarzeniem bardzo znaczącym. Legislacja wschodnia jest bowiem wyrazem poszanowania godności wszystkich katolickich Kościołów wschodnich, jednocześnie odzwierciedlającą ich autentyczną i starożytną dyscyplinę. Niestety, nie sposób uznać za powszechne i zgodne w doktrynie przekonanie o całkowitej autonomii tegoż zbioru, trudności sprawia także kwestia możliwości stosowania obu Kodeksów jako pomocniczych względem siebie w interpretacji ustaw wattpliwych lub w przypadku luki prawnej. Kwestia jest nie tylko teoretyczna, albowiem w obu Kodeksach nie brakuje norm dotyczących bezpośrednio lub przynajmniej pośrednio także katolików, którzy zasadniczo danej legislacji nie podlegają. Innymi słowy w KKKW znajdziemy normy odnoszące się także do katolików łacińskich, również w KPK nie brak norm dotyczących wiernych innego obrzqdku.

Celem niniejszego artykułu jest zatem analiza sytuacji prawnej, jaka zaistniała po promulgacji w 1990 r. KKKW. Jaki jest jego charak- 
ter względem obowiązującego KPK? Które normy wschodnie odnoszą się także do łacinników, w konsekwencji czego powinny być przez nich znane i stosowane? I w końcu, czy Kodeks wschodni może być stosowany jako pomocnicze źródło interpretacji w przypadku norm wątpliwych lub jako legislacja uzupełniająca braki istniejące w KPK?

\section{Zasada wspólistnienia, ale nie podporządkowania KPK i KKKW}

Wydawałoby się, że autonomia dwóch Kodeksów kanonicznych jest czymś oczywistym i nie wymagającym uzasadniania. Wynika to już choćby z samego faktu, że zakres odbiorców, do których adresowany jest każdy z tych zbiorów, jest zupełnie inny. Zgodnie z dyspozycją kan. 1 KPK Kanony tego Kodeksu dotycza jedynie Kościoła łacińskiego; podobna dyspozycja znalazła się także w kan. 1 KKKW (kanony tego Kodeksu odnosza się do wszystkich i jedynie do katolickich Kościołów Wschodnich), w którym jednak zostało dodane istotne doprecyzowanie: chyba że wyraźnie co innego zostało postanowione odnośnie do relacji z Kościołem łacińskim - o czym poniżej. Wydaje się, że takie określenie nie pozostawia żadnych wątpliwości w tym, co dotyczy istnienia i obowiązywania Kodeksów. A jednak, gdy w 1991 r. na Międzynarodowym Kongresie „Incontro fra canoni d'oriente e d'occidente" Dolores García Hervás mówił o znaczeniu dla Kościoła Kodeksu wschodniego, wyraził wówczas przekonanie, że nie jest możliwe istnienie jednego porządku prawnego opartego na dwóch różnych Kodeksach (tak jak nie jest możliwe istnienie dwóch kodeksów cywilnych w państwie) i z tego powodu jedynym Kodeksem powszechnym, obowiązującym wszystkich katolików, bez względu na obrządek, do którego należą, byłby Kodeks łaciński. Kodeks wschodni natomiast miałby charakter jedynie pomocniczy, czyli nie byłby prawdziwym Kodeksem, ale prawem specjalnym, podporządkowanym Kodeksowi łacińskiemu. Natomiast pojedyncze normy tego prawa specjalnego mogą - zdaniem Autora - albo konstytuować szczególną legislację, która koresponduje ze specyficznym charakterem czy tradycją danej grupy, dla której zostały wydane (czyli wiernych katolickich Kościołów wschodnich), albo stanowić rozwój, dokonany przez pra- 
wodawcę, a dotyczący jakiejś materii wspólnej, poprzez który automatycznie zmieniałoby się prawo powszechne zawarte w KPK ${ }^{1}$.

Stanowisko takie wydaje się niemożliwe do zaakceptowania, nie można bowiem uznać funkcjonowania Kodeksu wschodniego za lex specialis w stosunku do prawa łacińskiego. Nie to było wola prawodawcy kościelnego i nie taki był zamysł papieży zaangażowanych od lat w proces kodyfikacji prawa wschodniego. Swiadczy o tym choćby fakt, że podczas prac nad kodyfikacją Kodeksu wschodniego zostały odrzucone wszystkie propozycje dążące do zbyt daleko idącego rozciagnięcia mocy obowiązującej KKKW także na wiernych łacińskich $^{2}$. Co więcej, w konstytucji apostolskiej Sacri canones, poprzez którą papież Jan Paweł II promulgował KKKW, prawdziwa intencja prawodawcy wyrażona została w sposób niepozostawiający żadnych wątpliwości: kanony Kodeksu katolickich Kościołów wschodnich musza posiadać tę sama moc co przepisy Kodeksu Prawa Kanonicznego Kościoła łacińskiego, to jest obowiazywać, dopóki nie zostanq uchylone badź zmienione przez najwyższq władze kościelnq ze stusznych przyczyn $(\ldots)^{3}$. Dlatego, jak wszystkie katolickie Kościoły Wschodu i Zachodu jednakowa posiadaja godność $i$ żaden z nich nie góruje nad innymi z racji obrzqdku (OE 3), tak też jednakową moc obowiązująca posiadają oba Kodeksy, które wraz z Konstytucją apostolską Pastor bonus tworzą jeden Corpus Iuris Canonici Kościoła katolickiego. Nie ma zatem żadnych podstaw, aby uznawać Kodeks wschodni za mniej lub bardziej istotny, bardziej ogólny bądź uszczegóławiający wcześniejsze prawo, jako legislację późniejsza, a w konsekwencji znoszącą czy zmieniającą lub uzupełniającą prawo dawniejsze. Dlatego nawet gdy pewne normy legislacji wschodniej regulują kwestie nieuregulowane w KPK albo gdy normują je w sposób sprzeczny lub przynajmniej inny niż zbiór łaciński, to nie jest uzasadnione

${ }^{1}$ Por. D. García Hervás, La significación para la Iglesia del nuevo Código Oriental, w: R. Coppola (red.), Atti del Congresso internazionale "Incontro fra canoni d'oriente e d'occidente", vol. 2, Bari 1994, s. 41-47.

2 Nisi de relationibus interitualibus agitur, quae latinos quoque respiciunt - Nuntia 22 (1986), s. 13-14; Nisi ex natura rei vel expresse aliud statuatur - Nuntia 28 (1989), s. 13.

3 Ioannes Paulus II, Constitutio Apostolica Sacri canones venerabilibus fratribus patriarchis, archiepiscopis, episcopis, ac dilectis filiis presbyteris, diaconis ceterisque christifidelibus orientalium ecclesiarum, AAS 82 (1990), s. 1035-1036. 
stosowanie Kodeksu wschodniego w stosunku do wiernych łacińskich tylko dlatego, że mamy do czynienia z późniejszą normą tego samego prawodawcy ${ }^{4}$. Co więcej, wielu Autorów uzasadnia także, że Kodeks wschodni, nawet jeśli reguluje prawne relacje międzyobrządkowe, których brak w KPK, nie może obowiązywać wiernych łacińskich ex natura rei. Choć równie często spotkać można zdania przeciwne - tak jest choćby w przypadku licznych kazusów dotyczących przynależności kościelnej ${ }^{5}$ - to jednak Peter Erdö oraz Marco Brogi jako kontrargument podają treść Rescriptum ex Audientia Ss.mi. Sekretariatu Stanu z 28 listopada 1992 r. Otóż mocą tegoż Reskryptu niejako uzupełniona została treść kan. $112 \mathrm{KPK}$, poprzez wprowadzenie domniemania dotyczącego zgody Stolicy Apostolskiej na zmianę Kościoła sui iuris ${ }^{6}$. Domniemania, które w swej treści zawiera kan. 32 $\S 2$ KKKW. W ten sposób - zdaniem wymienionych Autorów - należy wnioskować, że dyspozycja wschodnia, odnosząca się do relacji pomiędzy różnymi Kościołami sui iuris, ale niezawierająca wzmianki o Kościele łacińskim, nie obowiązywała wiernych łacińskich nawet ,z natury rzeczy"7.

${ }^{4}$ P. ERDö, Questioni interordinamentali tra la Chiesa latina e le Chiese cattoliche orientali, w: E. RAAD (red.), Sistema giuridico canonico e rapport interordinamentali. Atti dell'XII. Congresso Internazionale di Diritto Canonico, Beyrouth 2008, s. 29-30; F.J. Urrutia, Canones praeliminares Codicis (CIC). Comparatio cum canonibus praeliminaribus Codicis Canonum Ecclesiarum Orientalium (CC), Periodica 81 (1992), s. 158; M. Brogi, Il nuovo codice orientale e la Chiesa latina, Antonianum 66 (1991), s. 46-49.

5 Por. J. PRAder, La legislazione matrimoniale latina e orientale. Problemi interecclesiali, interconfessionali e interreligiosi, Roma 1993, s. 16; P. ERDÖ, Questioni interrituali (interecclesiali) del diritto dei sacramenti (battesimo e cresima), Folia Canonica 1 (1998), s. 23; L. Lorusso, Gli orientali cattolici e i pastori latini. Problematiche e norme canoniche, Kanonica 11, Roma 2003, s. 63.

${ }^{6}$ Ad normam can. 112, $\S 1,1^{\circ}$ Codicis Iuris Canonici, quisque vetatur post susceptum Baptismum alii ascribi Ecclesiae rituali sui iuris, nisi licentia ei facta ab Apostolica Sede. Hac de re, probato iudicio Pontificii Consilii de Legum Textibus Interpretandis, Summus Pontifex Ioannes Paulus II statuit eiusmodi licentiam praesumi posse, quoties transitum ad aliam Ecclesiam ritualem sui iuris sibi petierit Christifidelis Ecclesiae Latinae, quae Eparchiam suam intra eosdem fines habet, dummodo Episcopi dioecesani utriusque dioecesis in id secum ipsi scripto consentiant. - AAS 85 (1993), s. 81.

7 P. ERDö, Questioni interordinamentali..., art. cyt., s. 30; M. BRoGI, Licenza presunta della Santa Sede per il cambiamento di Chiesa sui iuris, Revista Española de Derecho Canonico 50 (1993), s. 667. 


\section{Zasada nisi, relationes cum Ecclesia latina quod attinet, aliud expresse statuitur}

Autonomia Kodeksów nie oznacza jednak, że pomiędzy nimi nie ma żadnej zależności i że w żaden sposób ich normy nie łączą się ze sobą. Jak pisze Peter Erdö, plena communio, jaka istnieje pomiędzy wszystkimi Kościołami katolickimi, domaga się uznania warunków ontologiczno-prawnych poszczególnych wiernych, przez co niezależności dwóch systemów - łacińskiego i wschodniego - nie należy rozumieć w sensie autonomii hermetycznej ${ }^{8}$.

I rzeczywiście, przede wszystkim należy wziąć tu pod uwagę wspomniany wyżej kan. $1 \mathrm{KKKW}$, który zawiera klauzulę chyba że wyraźnie co innego zostało postanowione odnośnie do relacji z Kościołem łacińskim. Otóż w legislacji wschodniej w tenże sposób wyraźnie postanowiono - poza dyspozycją kan. 1 KKKW - jeszcze dziewięciokrotnie:

1) Kan. 37 KKKW: adnotacja w księgach ochrzczonych

Zgodnie z ogólną zasadą szafarze katoliccy mogą ważnie i godziwie udzielać sakramentów wszystkim wiernym katolikom - a zatem również należącym do innych Kościołów katolickich - a wierni katolicy mogą sakramenty od tychże szafarzy przyjmować (KPK, kan. 844 $\S 1$; KKKW, kan. $671 \S 1$ ). Dotyczy to także sakramentu chrztu św., przy czym należy pamiętać, że o przynależności kościelnej wiernych nie decyduje ani ryt liturgiczny chrztu, ani miejsce jego przyjęcia, ale norma prawa9. Majac to na uwadze, prawodawca wschodni zobowiązuje do dokonania adnotacji o przyjęciu chrztu oraz o zmianie przynależności kościelnej w księdze ochrzczonych parafii, w której chrzest został udzielony, także jeśli tym miejscem udzielenia była parafia Kościoła łacińskiego. Jak pisze Carl Gerold Fürst, jest to logiczne i konieczne uzupełnienie kan. $535 \S 2 \mathrm{KPK}^{10}$, ale również kan. $877 \S$ 1 KPK. Stanowi to obowiązek o tyle istotny, że od jego zachowania mogłaby zależeć nawet ważność małżeństwa. Proboszcz łaciński nie

${ }^{8}$ P. ERDö, Questioni interordinamentali..., art. cyt., s. 31.

${ }^{9} \mathrm{Na}$ ten temat szerzej zob. U. Nowicka, Przynależność wiernych do Kościoła wg $K K K W$ i KPK, Prawo Kanoniczne 53 (2010), nr 1-2, s. 269-298.

${ }^{10}$ Por. C.G. FürST, Interdipendenza del diritto canonico latino e orientale, w: K. Bharanikulangara, Il Diritto Canonico Orientale nell'ordinamento ecclesiale, Studi Giuridici XXXIV, Città del Vaticano 1995, s. 24. 
jest bowiem kompetentny, aby asystować przy małżeństwie osób nawet ochrzczonych w Kościele łacińskim, ale według normy prawa należących do któregoś z katolickich Kościołów wschodnich (por. kan. $1109 \mathrm{KPK})$.

2) Kan. 41 KKKW: pouczenie o obrządkach

Kan. $41 \mathrm{KKKW}$ jest wyrazem poszanowania godności wszystkich obrządków katolickich i jednocześnie dbałości o zachowanie i rozwój wszystkich Kościołów sui iuris. Było to wyrazem szczególnej troski Ojców soborowych, którzy nieustannie przypominali, aby wierni chrześcijanie wschodni zawsze zachowywali swoje prawowite obrzędy liturgiczne i swoje zasady karności (OE 6), ponieważ różnorodność w Kościele nie tylko nie przynosi szkody jego jedności, ale ja raczej uwydatnia (OE 2). Dlatego prawodawca zobowiązuje wszystkich wiernych, także należących do Kościoła łacińskiego, którzy z uwagi na charakter swojej pracy utrzymują częste kontakty z chrześcijanami innego Kościoła sui iuris, aby byli pouczeni o tym Kościele, o jego obrzędach, karności, nauce, historii oraz duchu.

\section{3) Kan. 207 KKKW: wizyta ad liminam}

Biskupi katolickich Kościołów wschodnich, tak jak biskupi łacińscy, zobowiązani są prawnie do przedstawiania pięcioletnich relacji o stanie powierzonej sobie eparchii ${ }^{11}$. Sprawozdania takie musza zawierać także informacje dotyczące wiernych. Prawodawca, biorąc pod uwagę sytuacje, w których wierni należący do jednego Kościoła powierzani są trosce duszpasterskiej ordynariusza (hierarchy) innego Kościoła - o czym poniżej - zobowiązuje wszystkich biskupów, także łacińskich, aby w tychże pięcioletnich relacjach uwzględniali także stan i potrzeby wiernych powierzonych swojej trosce. Obowiązek taki wydaje się naturalny, skoro bowiem ordynariusz łaciński, z woli ustawodawcy, staje się własnym ordynariuszem pewnej grupy wiernych katolików wschodnich, a oni jego wiernymi, to ma wobec nich te same prawa i obowiązki, co wobec wiernych własnego Kościoła.

11 Biskupi eparchialni wykonujący swoją władzę w granicach terytorium Kościoła patriarchalnego sprawozdania takie przedstawiają patriarsze (egzemplarz relacji wysyłany jest również do Stolicy Apostolskiej), zaś pozostali biskupi - Stolicy Apostolskiej - zob. KKKW, kan. 206. 
4) Kan. 322 § 1 KKKW: zgromadzenie hierarchów wielu Kościołów sui iuris

Kan. $322 \S 1$ KKKW, jedyny w Tytule IX tegoż zbioru, normuje kwestie dotyczące zgromadzeń hierarchów wielu Kościółów sui iuris. Takie zgromadzenia są podobne do łacińskich konferencji episkopatu, przynajmniej na stopniu instytucjonalnym, nie posiadaja jednak ich władzy ustawodawczej ${ }^{12}$. Rzeczywiście, motu proprio Apostolos suos $\mathrm{w}$ przypisie 1 zawiera wyjaśnienie, że Kościoły wschodnie patriarchaty $i$ arcybiskupstwa większe - sq rzqdzone przez wtasne Synody Biskupów, wyposażone we władzę ustawodawcza, sqdownicza, a w pewnych przypadkach także administracyjnq (...): niniejszy dokument ich nie dotyczy (...). Dotyczy natomiast zgromadzeń ustanowionych $w$ regionach, w których istnieje więcej Kościolów sui iuris oraz regulowanych przez $K K K W$, kan. 322 i odpowiednie statuty zatwierdzone przez Stolice Apostolska (...), w takiej mierze, w jakiej charakter tych zgromadzeń jest zbliżony do konferencji episkopatu. Celem tychże zgromadzeń jest wymiana doświadczeń, metod i udzielanie rad, dzięki którym ma dokonywać się święte zjednoczenie sit dla dobra wspólnego Kościołów, wspierajace jedność działania $i$ wspólne dzieło, rozszerzajace dobro wiary i skuteczniej zachowujace dyscypline kościelnq. Prawodawca zaleca, aby na takie spotkania byli zwoływani wszyscy hierarchowie różnych Kościołów sui iuris, którzy wykonują władzę w tym samym narodzie lub regionie, także hierarchowie Kościoła łacińskiego.

5) Kan. 432 KKKW: monastery zależne, domy lub prowincje innego rytu

W dekrecie soborowym Orientalium ecclesiarum, n. 6 znalazło się usilne zalecenie, aby dla większej skuteczności apostolskiej pracy zakony $i$ stowarzyszenia obrzqdku tacińskiego zakładaty domy albo nawet prowincje obrzqdku wschodniego, o ile to tylko jest możliwe. Taką samą możliwość, za zgodą Stolicy Apostolskiej, daje prawodawca w kan. $432 \mathrm{KKKW}$, zastrzegając jednak, że ilekroć jakikolwiek instytut religijny, także łaciński, tworzy monastery zależne, domy lub pro-

12 Por. L. Lorusso, Interrelazione dei due Codici nella Chiesa, w: S. Agrestini, D. Ceccarelli Morolli (red.), Ius Ecclesiarum vehiculum caritas. Atti del simposio internazionale per il decennale dell'entrata in vigore del Codex Canonum Ecclesiarum Orientalium, Città del Vaticano 2004, s. 295. 
wincje innego rytu, tenże ryt ma być w nich wiernie zachowywany przy jednoczesnej konieczności przestrzegania typików i statutów instytutu, regulujących jego wewnętrzny zarząd oraz przywilejów przyznanych przez Stolicę Apostolską.

6) Kan. $696 \S \S 1-2$ KKKW: szafarstwo chryzmacji

W pierwszych wiekach Kościoła bierzmowanie stanowiło zazwyczaj jeden obrzęd z chrztem, tworząc razem z nim ,podwójny sakrament" ${ }^{13}$. W Kościołach wschodnich praktyka ta zachowała się do dnia dzisiejszego ${ }^{14}$, w Kościele łacińskim, w którym dopełnienie chrztu chciano zarezerwować dla biskupa, wprowadzono rozdzielenie w czasie obu sakramentów ${ }^{15}$. Konsekwencją tej różnorodności jest fakt, że w Kościołach wschodnich każdemu prezbiterowi wolno udzielać sakramentu chryzmacji, czy to łącznie z chrztem, czy oddzielnie; w Kościele łacińskim bierzmowanie jest - co do zasady - udzielane wiele lat po chrzcie, a jego zwyczajnym szafarzem jest jedynie biskup (KPK, kan. 882). Ale to nie wierny łaciński jest niezdolny do przyjęcia sakramentu bierzmowania od prezbitera, tylko prezbiter łaciński nie ma prawa tego sakramentu udzielić. Dlatego w kan. $696 \S \S 1-2$ KKKW prawodawca upoważnia wszystkich prezbiterów wschodnich do udzielania chryzmacji wszystkim wiernym katolikom, również łacińskim, zaś wiernym wschodnim zezwala na przyjmowanie tego sakramentu również od prezbiterów łacińskich - ale jedynie według uprawnień, które oni posiadają. Takie zastrzeżenie jest jak najbardziej słuszne, w przeciwnym bowiem razie prawodawca wschodni ingerowałby $\mathrm{w}$ uprawnienia prezbiterów łacińskich, czego nie wolno mu czynić.

7) Kan. $830 \S 1$ KKKW: przekazanie upoważnienia do błogosławienia małżeństw

Wszyscy ci, którzy cieszą się upoważnieniem zwyczajnym błogosławienia małżeństw, dopóki ważnie sprawują swój urząd, mogą je przekazać (KKKW nie używa w tym przypadku terminu delegacja), wewnątrz granic swojej kompetencji, innemu kapłanowi. W kan. 830

\footnotetext{
13 KKK, n. 1290.

14 Por. KKKW, kan. 695 § 1.

15 KKK, n. 1290.
} 
$\S 1$ KKKW prawodawca precyzuje, że owym innym kapłanem może być także kapłan łaciński - i tylko kapłan, jako że prawodawca wschodni, biorąc pod uwagę rolę błogosławieństwa w zawieraniu małżeństwa, wyklucza możliwość przekazania takiego uprawnienia diakonom i osobom świeckim. Norma ta jednak tylko pozornie wydaje się jasna i niebudząca trudności interpretacyjnych. W sytuacji bowiem, gdy kapłan łaciński ma - na mocy upoważnienia hierarchy lub proboszcza wschodniego - błogosławić małżeństwo wiernych katolików wschodnich, pojawia się wątpliwość dotycząca rytu liturgicznego, jaki powinien być wówczas stosowany ${ }^{16}$. Otóż zgodnie z kan. $846 \S 2 \mathrm{KPK}$ oraz kan. $674 \S 2$ KKKW szafarz powinien sprawować sakramenty według przepisów liturgicznych własnego Kościoła sui iuris. Na tej podstawie tacy autorzy jak Joseph Prader czy Lorenzo Lorusso stwierdzają i słusznie - iż także w przypadku, w którym celebrans jest z innego Kościoła sui iuris niż nupturienci, musi on stosować ryt liturgiczny własnego Kościoła, a nie ryt liturgiczny Kościoła przyszłych małżonków. Oznacza to, że kapłan łaciński, który błogosławi małżeństwo wiernych wschodnich, musi stosować własny ryt liturgiczny, chyba że otrzymał od Stolicy Apostolskiej indult birytualizmu ${ }^{17}$.

Tymczasem 6 stycznia 1996 r. Kongregacja Kościołów Wschodnich opublikowała Instrukcję dotyczqca aplikacji przepisów liturgicznych Kodeksu Kanonów Kościołów Wschodnich. Zaskakująca jest treść n. 83 tejże Instrukcji ${ }^{18}$, także zaskakująca jest jego interpretacja spotykana w doktrynie kanonistycznej. Na podstawie Instrukcji należałoby bowiem sądzić, że w sytuacji, w której na podstawie upoważnienia przekazanego przez hierarchę miejsca lub proboszcza miejsca wschod-

${ }^{16}$ Szerzej na ten temat zob. U. NowickA, La forma canonica di celebrazione del matrimonio. Problemi interecclesiali, w: J. Kowal, J. Llobell (red.), Iustitia et Iudicum. Studi di diritto matrimoniale e processuale canonico in onore di Antoni Stankiewicz, vol. II, Città del Vaticano 2010, s. 903-921.

17 Por. J. Prader, Il diritto matrimoniale latino e orientale: studio comparativo, w: S. Gherro (red.), Studi sul Codex Canonum Ecclesiarum Orientalium, Roma 1994, s. 64; L. LoRusso, Gli orientali cattolici...., dz. cyt., 256.

${ }_{18}$ Occorre tuttavia tener presente che, con l'eccezione del caso In cui il Gerarca o il parroco siano, a norma del can. 916 del Codice dei Canoni delle Chiese Orientali, di altra Chiesa sui iuris, la celebrazione deve avvenire, ad liceitatem, secondo il rito liturgico degli sposi, o di uno di loro in caso di matrimonio interrituale. Una celebrazione in altro rito è dunque illecita, ma può essere autorizzata caso dalla Sede Apostolica. 
niego kapłanowi łacińskiemu do pobłogosławienia małżeństwa, w którym obie strony należą do katolickich Kościołów wschodnich, wymagane jest, aby celebracja odbyła się w obrządku wschodnim nupturientów. Z Instrukcji wynika, że celebrans, prawnie delegowany, czyni to wówczas bez żadnego dodatkowego zezwolenia, a zatem także bez indultu birytualizmu. Wręcz przeciwnie, gdyby ów kapłan łaciński miał celebrować sakrament małżeństwa wiernych wschodnich w obrządku łacińskim, z powodu choćby nieznajomości obrządku albo z woli samych nupturientów ${ }^{19}$, wówczas ad liceitatem konieczny byłby specjalny reskrypt Stolicy Apostolskiej. Czyli - innymi słowy - konieczne jest zezwolenie na celebrowanie liturgii małżeństwa we własnym obrządku. Wątpliwości budzi fakt, iż Instrukcja - będąc jedynie aktem wykonawczym w stosunku do KKKW - zawiera normę odwrotną do tej, która znajduje się w obu Kodeksach kanonicznych. Nie wydaje się możliwa, a jednocześnie właściwa opinia, jakoby ta norma (Instrukcja, n. 83) uchylata normę ogólnq ustanowiona w obu Kodeksach, wg której szafarz musi celebrować sakramenty wg własnego rytu (KKKW kan. $674 \S 2 ; K P K, k a n .846 \S 2)^{20}$. Instrukcja wydana przez Kongregacje Kościołów Wschodnich nie jest dokumentem mającym moc zmieniania prawa powszechnego ustanowionego w Kodeksie, ani wschodnim, ani tym bardziej łacińskim. Jest jedynie ogólną wskazówką, sformułowaną jako owoc różnorodności i bogactwa własnego doświadczenia ${ }^{21}$. Ale to Kodeks pozostaje podstawowym dokumentem najwyższego ustawodawcy kościelnego, a w konsekwencji to wszystko, co pozostaje z nim niezgodne, nie obowiązuje. Takie stanowisko reprezentuje Lorenzo Lorusso, który w jednej ze swoich recenzji pisze: jest sprzeczność pomiędzy Instrukcja, n. 83 a Kodeksem; zatem sqdzimy, że wobec takiej sprzeczności należy zachować norme Kodeksowa ${ }^{22}$. Jest także

19 Por. K. Nitkiewicz, Małżeństwo wiernych katolickich Kościołów wschodnich zawierane wobec duchownego Kościoła łacińskiego, w: T. PŁoski, J. KRzYwkowskA (red.), Małżeństwo i rodzina w prawie kanonicznym, polskim i międzynarodowym. Księga pamiątkowa dedukowana ks. prof. R. Sztychmilerowi, Olsztyn 2008, s. 182.

20 D. Salachas, K. Nitkiewicz, Rapporti interecclesiali tra cattolici orientali e latini. Sussidio canonico-pastorale, Roma 2007, s. 79.

${ }^{21}$ Ionnnus Paulus II, Discorso del Santo Padre ai partecipanti alla Plenaria della Congregazione per le Chiese Orientali, 01.10.1998, n. 7.

${ }_{22}$ L. Lorusso (rec.), D. Salachas, K. NitKIEWICZ, Rapporti interecclesiali tra cattolici orientali e latini. Sussidio canonico-pastorale, Roma 2007, Ius Missionale II/2008, s. 323-324. 
prawda, że nie wydaje się racjonalne, aby kapłan łaciński, asystując i błogosławiąc małżeństwo dwojga wiernych wschodnich, musiał celebrować je w rycie wschodnim, chcąc zaś stosować ryt własny, musiał uzyskać zezwolenie Stolicy Apostolskiej ${ }^{23}$.

8) Kan. $916 \S 5$ KKKW: opieka duszpasterska nad wiernymi bez hierarchii własnego Kościoła sui iuris

Nie są rzadkie sytuacje, zwłaszcza na terytoriach łacińskich, kiedy brak jest struktur jakiegoś Kościoła sui iuris, mimo że na tymże terytorium zamieszkują wierni do niego należący. Prawodawca wschodni nie pozostawia ich jednak bez opieki własnego pasterza. Gdy bowiem na danym terytorium nie istnieje hierarchia dla wiernych chrześcijan określonego Kościoła sui iuris, a terytorium to znajduje się poza granicami Kościoła patriarchalnego lub chodzi o wiernych Kościoła sui iuris inny niż patriarchalny ${ }^{24}$, wówczas z woli prawodawcy - zakładając, że na przedmiotowym terytorium jest tylko jeden hierarcha miejsca innego Kościoła sui iuris z wymaganą jurysdykcją - to on jest uważany za hierarchę własnego tych wiernych, nawet jeśli owym jedynym hierarchą jest ordynariusz łaciński. Gdy zaś obok ordynariusza łacińskiego (lub innego) będzie na danym terytorium istnieć także hierarchia katolickiego Kościoła wschodniego, jednak nie Kościoła sui iuris wiernych, o których chodzi, wówczas za hierarchę własnego tych wiernych należy uważać tego (ordynariusza łacińskiego lub hierarchę wschodniego), który zostanie wyznaczony przez Stolicę Apostolską, lub, jeśli mówi się o wiernych chrześcijanach jakiegoś Kościoła patriarchalnego lub arcybiskupstwa większego, przez patriarchę lub arcybiskupa większego za zgodą Stolicy Apostolskiej.

9) Kan. 1465 KKKW: prozelityzm

Sankcja karna przewidziana w kan. 1465 KKKW jest konsekwencją zakazu ustanowionego w kan. 31 KKKW: Nikt nie może przymuszać w żaden sposób żadnego chrześcijanina do przejścia do innego Kościoła sui iuris. Jest także wyrazem wielkiej troski Kościoła z jed-

${ }^{23}$ Por. tamże, s. 324.

${ }^{24} \mathrm{~W}$ przeciwnym wypadku wewnątrz terytorium Kościoła patriarchalnego w miejscach, w których nie została ustanowiona ani eparchia, ani nawet egzarchat wschodni, Patriarcha jest własnym biskupem eparchialnym dla wiernych tam zamieszkujących, a zatem posiada te same prawa i obowiązki co on. 
nej strony o zachowanie bogactwa rytów, z drugiej także o wolność sumienia każdego wiernego. W interpretacji tego kanonu pojawia się jednak pewna wątpliwość: otóż na jego mocy sprawiedliwą karą powinien być ukarany każdy, kto, wykonując w jakimkolwiek Kościele sui iuris, także w Kościele łacińskim, urząd, posługę lub inne zadanie, nakłania kogokolwiek i w jakikolwiek sposób do przejścia do innego Kościoła sui iuris. Valesio De Paolis, interpretując tę normę, pisze, że nakłada ona sankcję karną także na wiernych Kościoła łacińskiego, mimo że przepisy KKKW ich nie obowiąująa 25 . I słusznie, bo tak właśnie wynika z treści kan. 1465 KKKW. Czy jednak właściwe jest, że Kodeks wschodni nakłada karę na wiernych łacińskich, karę, która w legislacji łacińskiej nie istnieje? Zwłaszcza jeśli weźmie się pod uwagę treść kan. $19 \mathrm{KPK}$ - o którym będzie mowa poniżej - iż jeśli w określonej sprawie brak wyraźnej ustawy (...), sprawa - z wyjatkiem karnej - winna być rozstrzygnięta z uwzględnieniem ustaw wydanych $w$ podobnych sprawach (...). Wydaje się jednak, że w tym przypadku należy brać pod uwagę i stosować treść kan. $1 \mathrm{KKKW}$ chyba że wyraźnie co innego zostało postanowione odnośnie do relacji z Kościołem łacińskim. W tym miejscu rzeczywiście wyraźnie zostało postanowione. A konkretnie - wyraźnie postanowił ten sam prawodawca, który promulgował także KPK. I to z jego woli, w opisywanej sytuacji, kan. 1465 KKKW obowiązuje nie tylko katolików wschodnich, ale również wiernych łacińskich.

\section{Kościół sui iuris a Ecclesia latina w normach KKKW}

Nie ma wątpliwości, że ,skuteczność” Kodeksu wschodniego w stosunku do wiernych łacińskich nie wyczerpuje się w normach, które w swej treści zawierają sformułowanie Ecclesia latina. George Nedungatt w prezentacji włoskiego tłumaczenia Kodeksu wschodniego mówił, że oprócz powyższych są także inne kanony, w których, chociaż Kościół łaciński nie jest wymieniany wyraźnie, niewątpliwie mieści się on w pojęciu Kościoła sui iuris, chociaż różni się od czterech typów Kościołów sui iuris, wymienionych w KKKW. Wśród nich wymienił te, które dotyczą nabycia i zmiany przynależności kościelnej (KKKW, kann. 29-41), jedności działań duszpasterskich ze

${ }^{25}$ V. De Paolis, Commento al can. 1465, w: P.V. Pinto (red.), Commento al Codice dei Canoni delle Chiese Orientali, Città del Vaticano 2001, s. 1151. 
strony biskupów wykonujących władzę na tym samym terytorium w zakresie popierania jedności chrześcijan (KKKW, kan. $84 \S 1$; kan. 202), w tym także tworzenia komisji biegłych dla spraw ekumenicznych (KKKW, kan. $904 \S 2$ ), ustanowienia takich samych norm o taksach i ofiarach (KKKW, kan. $1013 \S 2$ ), ujednolicenia ustaw karnych prawa partykularnego (KKKW, kan. $1405 \S 3)^{26}$. Jednak i to jest wyliczenie egzemplaryczne, takich kanonów jest bowiem w KKKW znacznie więcej. Zgodnie z kan. $143 \S 3 \mathrm{KKKW}$ na zgromadzenie patriarchalne (a zatem również Kościoła arcybiskupiego większego - KKKW, kan. 152) mogą być zapraszane osoby należące do innych Kościołów sui iuris. Podobnie, jeśli chodzi o zgromadzenie Kościoła metropolitalnego sui iuris (KKKW, kan. 172) oraz zgromadzenie eparchialne (KKKW, kan. 238 §), a nawet rady duszpasterskie (KKKW, kan. $273 \S 3$ ). Biskup eparchialny, któremu zostali powierzeni wierni innych Kościołów sui iuris powinien zatroszczyć się o wszystko, aby mogli zachowywać i pielęgnować swój ryt, także ustanawiając dla ich spraw Syncela (odpowiednik łacińskiego wikariusza biskupiego) (KKKW, kan. 193 § 2), który również może być członkiem innego Kościoła sui iuris (KKKW, kan. 247 § 4). Kiedy w jakiejś eparchii istnieją terytoria, na których nie ma proboszcza dla wiernych określonego Kościoła sui iuris, biskup eparchialny może wyznaczyć dla nich proboszcza innego Kościoła sui iuris, za zgodą jego biskupa (KKKW, kan. 916 § 4). Prawodawca wschodni przewiduje możliwość erygowania seminariów wyższych, które służyłyby różnym Kościołom sui iuris, mającym eparchie w tym samym regionie lub kraju (KKKW, kan. $332 \S 2$ ), także program kształcenia duchownych może być wspólny dla wielu Kościołów sui iuris, z zastrzeżeniem, aby charakter obrzqdków nie doznat uszczerbku (KKKW, kan. 330 § 2). Duchowni mogą przynależeć (KKKW nie używa terminu inkardynacja) do eparchii Kościoła sui iuris innego niż własny bez zmiany przynależności kościelnej (KKKW, kan. 365 § 2). Natomiast dla godziwego przyjęcia do nowicjatu instytutu zakonnego innego Kościoła sui iuris potrzebna jest zgoda Stolicy Apostolskiej (KKKW, kan. 517 § 2); do przejścia do instytutu zakonnego lub stowarzyszenia życia wspólnego na wzór zakonników innego Kościoła sui iuris taka zgoda wymagana jest do

${ }^{26}$ Por. G. Nedungatt, Presentazione del CCEO, Enchiridion Vaticanum XII, s. $899-900$. 
ważności (KKKW, kan. 544 § 4; 562 § 1). Chociaż nauczanie doktryny chrześcijańskiej należy, w sposób szczególny, do każdego Kościoła sui iuris i jego hierarchii, to jednak jeśli na danym terytorium lub regionie socjo-kulturowym istnieją różne Kościoły sui iuris, wolno utworzyć wspólną dla nich komisję katechetyczną (KKKW, kan. 622 § 1). Jeśli chrzest ma być udzielany na obcym terytorium, proboszcz innego Kościoła sui iuris nie może odmówić pozwolenia kapłanowi Kościoła sui iuris, do którego należy przyjmujący chrzest (KKKW, kan. 678 $\S 1)$. W kan. $701 \mathrm{KKKW}$ prawodawca zezwala, dla słusznej przyczyny, na koncelebrację biskupów i prezbiterów różnych Kościołów sui iuris, za zgoda Biskupa eparchialnego, z przestrzeganiem wszystkich przepisów ksiag liturgicznych głównego celebransa, w sposób wolny od jakiegokolwiek synkretyzmu liturgicznego, przy czym pożadane jest zachowanie szat liturgicznych i insygniów własnego Kościoła sui iuris. Z kolei kan. 717 KKKW nakłada obowiązek na wszystkich kapłanów, aby - jeśli przyjmują ofiary z racji sprawowania Boskiej Liturgii od chrześcijan innego Kościoła sui iuris - zachowywali w odniesieniu do tychże ofiar normy tegoż Kościoła, jeśli co innego nie wynika ze strony ofiarodawcy. Przy konsekracji biskupa, biskupi współkonsekratorzy mogą należeć do innych Kościołów sui iuris (KKKW, kan. $746 \S 2$ ). Co się zaś tyczy święceń prezbiteratu, kandydata będącego podwładnym, a należącego do innego Kościoła sui iuris, biskup eparchialny może wyświęcić za zgodą Stolicy Apostolskiej (lub w określonych przypadkach - patriarchy) (KKKW, kan. 748 § 2). I w końcu w kan. 1068 § 1 KKKW przewiduje się możliwość, aby biskupi eparchialni różnych Kościołów sui iuris, wykonujący swoją władzę na tym samym terytorium, porozumieli się co do ustanowienia wspólnego trybunału, który będzie rozpoznawał sprawy tak sporne, jak i karne chrześcijan podległych któremuś z tych biskupów eparchialnych. Podobnie sędziowie i inni pracownicy trybunału mogą pochodzić z innego Kościoła sui iuris za zgodą wydaną na piśmie przez własnego biskupa eparchialnego (KKKW, kan. 1102).

\section{Komplementarność praktyczna KKKW i KPK jako jednego systemu prawnego}

Wiele spośród ww. kanonów nie ma swoich odpowiedników w KPK. Co więcej, istnieją także materie uregulowane w obu Kodeksach w sposób odmienny; inne, które na gruncie KPK pozostawały 
niejasne, budząc liczne dyskusje wśród kanonistów, teraz - w KKKW - doczekały się jasnej regulacji. A w związku z tym nie sposób nie zadać pytania, czy KKKW - będąc niewątpliwie zbiorem autonomicznym, mających równą godność i taką samą moc, może być wykorzystywany jako źródło pomocnicze w interpretacji norm niejasnych lub uzupełnianiu istniejących braków?

Zgodnie z kan. 17 KPK ustawy kościelne należy rozumieć wedtug znaczenia własnego słów rozumianych $w$ tekście $i$ kontekście; jeśli pozostaja watpliwe lub niejasne, trzeba odnieść się do miejsc paralelnych, jeśli takie sa, do celu i okoliczności ustawy $i$ myśli prawodawcy; ta sama zasada została ustanowiona w KKKW, kan. 1499. Co więcej, według kan. 19 KPK jeśli w określonej materii brakuje wyraźnej dyspozycji prawa, tak powszechnego jak i partykularnego czy zwyczajowego, sprawa - z wyjatkiem karnej - winna być rozstrzygnięta $z$ uwzględnieniem ustaw wydanych $w$ podobnych sprawach, ogólnych zasad prawnych z zachowaniem stuszności kanonicznej, jurysprudencji, praktyki Kurii Rzymskiej oraz powszechnej i statej opinii uczonych. KKKW, kan. 1501, zawiera zasadę bardzo podobną: Jeśli w określonej sprawie brak wyraźnej ustawy, sprawa, z wyjatkiem karnej, winna być rozstrzygnięta według kanonów Synodów i świętych Ojców, prawnych zwyczajów, ogólnych zasad prawa kanonicznego z zachowaniem stuszności, jurysprudencji kościelnej oraz powszechnej i stałej doktryny kanonicznej.

Znaczenie własne słów określane jest jako znaczenie technicznokanoniczne, które wynika przede wszystkim z tradycji kanonistycznej i z samego prawa, w którym wiele słów ma swój określony sens, ale także z powszechnego sposobu mówienia i pisania. To znaczenie własne słów należy następnie rozumieć $w$ tekście $i$ w kontekście. Kontekst - jak pisze Lorenzo Lorusso - jest nie tylko bezpośrednim zdaniem, paragrafem, kanonem, ale także artykułem, rozdziałem, tytułem, sekcją, częścią, księga, całym Kodeksem, a nawet całym Corpus Iuris Canonici $^{27}$. A skoro tak, to należy powiedzieć, że analizując normy KPK, należy wziąć pod uwagę także KKKW i odwrotnie. Co więcej, jeśli pozostaja one watpliwe lub niejasne, trzeba odnieść się do miejsc paralelnych, jeśli takie sq. Luigi Chiappetta definiuje miejsca paralelne jako miejsca, które traktują o tej samej materii w innym aspekcie lub

27 L. Lonusso, Interrelazione dei due Codici..., art. cyt., s. 283. 
w innych okolicznościach, lub używają tych samych wyrażeń. Mogą one - uzasadnia Autor - znajdować się nie tylko w danym Kodeksie, ale także $\mathrm{w}$ innych obowiązujących ustawach niezawartych $\mathrm{w}$ nim, co wynika z jednej strony z natury rzeczy, z drugiej także z tekstu kanonu. W jego treści, ad litteram powtarzającej treść kan. 18 KPK 1917, dokonano jednak znaczącego opuszczenia: otóż nie mówi się już o miejscach paralelnych Kodeksu, ale ogólnie o miejscach paralelnych, przez co należy rozumieć, że w zakres tego sformułowania zostały włączone także miejsca paralelne znajdujące się w każdym Kodeksie, jak i te istniejące $w$ innych ustawach ${ }^{28}$. Trzeba bowiem zakładać, że prawodawca nie chciał przeczyć sam sobie, ale chciał regulować daną materię w sposób logiczny i konsekwentny ${ }^{29}$. Dlatego miejsca paralelne dla KPK mogą znajdować się w KKKW i odwrotnie, zwłaszcza biorąc pod uwagę, że oba Kodeksy zostały promulgowane przez tego samego prawodawcę ${ }^{30}$.

Kryterium pomocniczym w interpretacji prawa jest także cel $i$ okoliczności ustawy. Każde prawo ma swój cel specyficzny, który różni się od wspólnego celu wszystkich praw Kościoła, który jest zgodny z jego misją: ze zbawieniem człowieka. Ten cel, charakterystyczny dla danej ustawy, nazywany jest przez kanonistów ratio legis ${ }^{31}$. Okoliczności mogą dotyczyć czasu, miejsca, środowiska, sytuacji społecznej i politycznej itp., które wpłynęły na wydanie danej ustawy ${ }^{32}$. Innymi słowy, chodzi o kontekst historyczny, w którym dana ustawa powstała, bezpośrednie przyczyny, które doprowadziły prawodawcę do jej wydania, miejsce, w którym została stworzona, osoby, będące jej adresatami ${ }^{33}$. Wydaje się, że to kryterium interpretacji, w odniesieniu do „wykorzystywania" norm Kodeksu wschodniego dla lepszego zrozumienia legislacji łacińskiej i odwrotnie, powinno być stosowane ze szczególną ostrożnością. Bo cel wspólny i zasadniczy prawa kościelnego pozosta-

${ }_{28}$ Por. L. Chiappetta, Prontuario di Diritto Canonico e Concordatario, Roma 1994, s. 656.

${ }^{29}$ Por. V. De Paolis, A. D’Auria, Le Norme Generali. Commento al Codice di Diritto Canonico. Libro Primo, Città del Vaticano 2008, s. 148.

${ }^{30}$ Por. D. Salachas, L. SABbarese, Codificazione latina e orientale e canoni preliminari, Roma 2003, s. 145.

31 Por. tamże; J. García Martín, Le norme generali del Codex Iuris Canonici, Roma 2006, s. 115.

32 Por. L. Lorusso, Interrelazione dei due Codici..., art. cyt., s. 285.

33 J. García Martín, Le norme generali..., dz. cyt., s. 115. 
je jeden i niezmienny, ale każdy w Kodeksów uwzględnia specyfikę i tradycję wiernych, dla których został wydany. Dlatego ów cel specyficzny, a zwłaszcza okoliczności ustawy, mogą w niektórych materiach różnić się pomiędzy sobą. Podobnie uwzględnienie mens Legislatoris ma nieco mniejszą wartość, jeśli chodzi o rozważania na temat możliwości stosowania norm obu Kodeksów względem siebie. Myśl prawodawcy, jak pisze Luigi Chiappetta, nie jest jego prywatną intencja, ale szczególnym motywem, który - w wykonywaniu jego publicznej funkcji - doprowadził do wydania określonej ustawy, z jej precyzyjnym znaczeniem i treścią oraz jego oczekiwaniem dotyczącym sposobu rozumienia i aplikacji samego prawa ${ }^{34}$. I choć prawodawca obu Kodeksów jest jeden - papież Jan Paweł II - to jednak należy wziąć pod uwagę, że ze względu na tradycję Kościoła łacińskiego i wschodniego ta myśl prawodawcy w określonych materiach może być różna. Choć z drugiej strony należy podkreślić to, co niewątpliwie było myślą prawodawcy wyrażoną przez niego w konstytucji Sacri canones, mianowicie komplementarność praktyczną trzech zbiorów: KPK, KKKW i Pastor bonus.

Jak wyżej wspomniano, prawo nie reguluje wszystkich bez wyjątku kwestii i wszystkich sytuacji życia ludzkiego. Nie może regulować, ponieważ ustawy wydawane na podstawie sytuacji teraźniejszych dotyczą przyszłości (KPK, kan. 9; KKKW, kan. 1494), a nie da się przewidzieć wszystkich okoliczności, które mogą domagać się uregulowania. Prawodawca nie pozostawia jednak tego problemu bez rozwiązania, określając, jak należy postępować w przypadku tzw. luki prawnej. W omawianym tutaj zagadnieniu - relacji pomiędzy dwoma Kodeksami Kościoła - na szczególną uwagę zasługuje kryterium określone w kan. $19 \mathrm{KPK}$, mianowicie ustaw wydanych $w$ podobnych sprawach. Czy takową dla KPK może stanowić KKKW i odwrotnie?

Kwestia jest problematyczna, zwłaszcza jeśli chodzi o tę drugą sytuację. Dimitrios Salachas zauważa, że w KKKW, gdy mówi się o źródłach uzupełniających, nie czyni się nawiązanie do ustaw wydanych w sprawach podobnych, ale do kanonów Synodów i świętych Ojców (KKKW, kan. 1501) oraz do starożytnego prawa Kościołów

${ }^{34}$ L. Chiappetta, Prontuario di Diritto Canonico..., dz. cyt., s. 656-657. 
Wschodnich (KKKW, kan. 2) ${ }^{35}$. Należałoby wówczas powiedzieć, że niemożliwe jest odwołanie się poprzez analogię $\mathrm{w}$ przypadku luki prawnej w KKKW ani do KPK, ani do Pastor bonus. Choć $\mathrm{z}$ drugiej strony trzeba wziąc pod uwagę, iż w tym przypadku poruszamy się wewnątrz jednego porządku prawnego (jednego Corpus Iuris Canonici); co więcej, wytyczne Papieskiej Komisji do Rewizji Kodeksu Kanonicznego Wschodniego wskazują wyraźnie na analogię prawną jako narzędzie służące uzupełnieniu luk prawnych poprzez odenisienie do innych źródeł prawa kościelnego ${ }^{36}$.

Ale nawet jeśli rzeczywiście taka analogia byłaby możliwa - choć wśród kanonistów nie ma $\mathrm{w}$ tym względzie zgodności - to $\mathrm{z}$ pewnością nie można tego kryterium stosować w sposób bezkrytyczny. Przede wszystkim, kiedy mówi się o aplikacji poprzez analogię, trzeba mieć pewność, że rzeczywiście istnieje prawdziwa lacuna legis. Jeśli bowiem w jednym z Kodeksów istnieje regulacja określonej instytucji, tyle że odmienna, rozstrzyganie z uwzględnieniem norm Kodeksu wschodniego (i odwrotnie) nie spełniałoby kryteriów ustanowionych prawnie. W tym przypadku mówiłoby się raczej o uchyleniu jednego prawa przez drugie - co jest niemożliwe. Ponadto, analogia nie może być aplikowana $\mathrm{w}$ zakresie ustaw karnych, jak również w przypadku ustaw unieważniających i uniezdalniających oraz tych, które podlegają interpretacji ścisłej ${ }^{37}$.

\section{Zakończenie}

Nie ma wątpliwości, że w Kościele katolickim Kościoły wschodnie stanowią mniejszość. Ale ponieważ tradycja tej mniejszości stanowi z kolei patrymonium Kościoła powszechnego, to nie ustępują one Kościołowi łacińskiemu ani godnością, ani rangą. Co więcej, jak wynika z powyższych analiz, normy kanoniczne tej mniejszości służą

35 D. Salachas, Problematiche interrituali nei due codici orientale e latino, Apollinaris 75 (1994), s. 641.

${ }^{36}$ In caso di eventuali lacune per completare le fonti di cui al numero precedente e per rendere il futuro Codice conforme alle esigenze attuali si potrà ricorrere, se necessario, alle altre fonti giuridiche ecclesiastiche - PONTIFICIA COMMISSIO CODICI IURIS Canonici Orientalis Recognoscendo, Principi direttivi per la revisione del Codice di Diritto canonico orientale, secondo principio, n. 3, Nuntia 3 (1976), s. 4.

37 J. Otaduy, Comentario al can. 19, w: AA.VV., Comentario exegético al Código de Derecho Canónico, vol I., Pamplona 1996, s. 385. 
także - jeśli wyraźnie zostało to postanowione - także większości łacińskiej. Stąd też (jak również z uwagi na relacje międzyobrządkowe, które jednak nie były tematem powyższego studium) konieczna i właściwa jest znajomość legislacji wschodniej i jej stosowanie.

Studiując KKKW, niejednokrotnie można nabrać przekonania, że jest on w pewien sposób owocem doświadczenia wynikającego z siedmioletniego już obowiązywania KPK. Nie brak bowiem norm określonych bardziej precyzyjnie, nie brakuje również kwestii, które dopiero teraz doczekały się uregulowania. Nie oznacza to jednak, że KKKW należy traktować jako nowelizację, suplement czy tym bardziej jako lex specialis. KKKW jest zbiorem autonomicznym, któremu podlegają wierni katolickich Kościołów wschodnich. Dlatego nie można bezkrytycznie czy automatycznie stosować norm wschodnich do łacinników tylko dlatego, że KKKW jest późniejszym zbiorem tego samego ustawodawcy. Gdyby taka była jego wola, z pewnością powiedziałby o tym wyraźnie, tak jak uczynił to w dziewięciu omawianych powyżej kanonach. Dlatego, choć w interpretacji KPK nie trzeba wykluczać również KKKW jako źródła, do którego wolno się odwołać, to jednak należy czynić to zawsze ze świadomością jego różnorodności i autonomii, a także specyfiki katolickich Kościołów wschodnich.

\section{The mutual correlation of CIC and CCEO in light of their autonomous operation}

After promulgation of Code of Canons of Oriental Churches in 1990, we encounter in canonical doctrine the view that the CCEO is lex specialis in regards to the CIC, or that the Eastern Code obliges the Latin faithful as the later norm of the same Supreme Lawgiver. On the other hand according to the CCEO Canon 1 „The canons of this Code affect all and solely the Eastern Catholic Churches, unless, with regard to relations with the Latin Church, it is expressly stated otherwise". This article aims to analyze the relationship between the two Codes of the Church: CCEO canons, which apply to the Latin faithful (direct and indirect interrelation) and possible application of the CCEO norms as ancillary source for the interpretation of the CIC. 